\title{
The prevalence of injuries in professional Turkish soccer players
}

\author{
Faruk Yamaner ${ }^{1}$, Hayrettin Gümüşdağ ${ }^{1}$, Alparslan Kartal ${ }^{1}$, M. Gümüş ${ }^{2}$, A. Güllü ${ }^{3}, 0$. Imamoğlu 4 \\ ${ }^{1}$ Hitit University, School of Physical Education and Sports, Çorum; ${ }^{2}$ Zonguldak Karaelmas University, School \\ of Physical Education and Sports, Zonguldak; ${ }^{3}$ Inönü University, School of Physical Education and Sports, \\ Malatya; 419 Mayıs University, School of Physical Education and Sport, Samsun, Turkey
}

\section{Summary}

Study aim: To assess the prevalence and anatomical sites of injuries in professional soccer players in one game season. Material and methods: A cohort of 510 professional male soccer players consisting of 48 goalkeepers, 194 defence players, 189 mid-field players and 79 forward players of the $1^{\text {st }}$ and $2^{\text {nd }}$ Turkish Professional Soccer Leagues in 2005 -2006 season were requested to submit questionnaire reports on all injuries they experienced.

Results: About $60 \%$ of all injuries pertained to lower extremities, another $25 \%$ to upper extremities, the most frequent being skin abrasions (about 24\%). The percentage of players who sustained injuries was lowest among midfield players (about $47 \%$ ) compared with other categories (nearly $70 \%$ ) but the average number of injuries per player was highest among them (8.1 vs. about 4.5). The risk of sustaining injury when playing a match amounted to 9.8\% for mid-field players; that was significantly $(\mathrm{p}<0.01)$ lower $(11.7-13.0 \%)$ than for other categories of players.

Conclusions: Football injuries are the major factor affecting players' performance. Thus, appropriate strategies, aimed at reducing injuries, ought to be implemented.

Key words: Football - Injuries - Injury risk - Anatomical sites

\section{Introduction}

Football is one of the most popular sports in the world [1,4,8,12], as many as about 200 million individuals playing that game, including about 200.000 professional players [10]. The popularity of professional football creates a big financial effect [14]. At the same time, football players are at a high risk of injuries $[2,7,9]$, that risk in professional football being about thousand times higher than in industry workers [1]. Every elite male football player is supposed to be exposed to injury at least once in a year, which affects his performance $[2,8]$. Sustained injuries are associated with health expenses; they decrease football club incomes because of the absence of top players and, thus, club success [14].

It is evident that knowing the type of injury, its anatomical localisation and playing position of the player is important not only to prevent injuries but also for selecting appropriate treatment. Thus, the aim of the study was to determine the prevalence of various types of injuries in relation to body parts and playing positions.

\section{Material and Methods}

A cohort of 510 professional male football players aged 22 - 29 years was studied in the season $2005-2006$. The cohort consisted of 48 goalkeepers, 194 defence players, 189 mid-field players and 79 forward players of the $1^{\text {st }}$ and $2^{\text {nd }}$ Turkish Professional Football Leagues. After having been informed about the scope and protocol of the study, the players were requested to fill questionnaires containing demographic questions and those pertaining to details of injuries they experienced; the players were interviewed by their club physicians. The clubs made the players' records available for the purpose of the study. All players gave their informed consents to participate. All matches were played on grass fields. The SPSS for Windows software was used in data analysis, the level of $\mathrm{p} \leq 0.05$ being considered significant.

\section{Results}

The results of the study are presented in Tables $1-4$. As follows from Table 1, most players had over 10 years 
of training experience and during the season 2005 - 2006 all of them played nearly 30 matches, on average (Table 2 ). About $70 \%$ of goal keepers, defence and mid-field players sustained injuries; the respective percentage of forward players was significantly $(\mathrm{p}<0.001)$ lower but they sustained significantly $(\mathrm{p}<0.001)$ more injuries per injured player compared with other categories (8.1 vs. 4.1 - 4.6). The risk of sustaining injury when playing a match amounted to $9.8 \%$ for mid-field players; that was significantly $(\mathrm{p}<0.01)$ lower $(11.7-13.0 \%)$ than for other categories (Table 2).
Table 1. Demographic data (\%) of professional football players aged $22-29$ years $(n=510)$

\begin{tabular}{llc}
\hline Variable & Category & $\%$ \\
\hline Education & Primary & 10.2 \\
& Secondary & 42.7 \\
& University & 47.1 \\
Marital status & Married & 40.6 \\
\multirow{2}{*}{ Training experience } & Single & 59.4 \\
& $5-10$ & 26.5 \\
& $11-15$ & 41.2 \\
& Over 15 & 32.3 \\
\hline
\end{tabular}

Table 2. Numbers of players, played matches and sustained injuries

\begin{tabular}{lccccc}
\hline Category of players & $\begin{array}{c}\text { Keepers } \\
\mathrm{n}=48\end{array}$ & $\begin{array}{c}\text { Defence } \\
\mathrm{n}=194\end{array}$ & $\begin{array}{c}\text { Mid-field } \\
\mathrm{n}=189\end{array}$ & $\begin{array}{c}\text { Forward } \\
\mathrm{n}=79\end{array}$ & $\begin{array}{c}\text { Total } \\
\mathrm{n}=510\end{array}$ \\
\hline Variable & 48 & 194 & 189 & 79 & 510 \\
Players (n) & 75.0 & 69.6 & 68.8 & $46.8^{* * *}$ & 66.3 \\
Injuries, total (n) & 167 & 639 & 533 & 299 & 1638 \\
Players×matches (n) & 1284 & 5396 & 5436 & 2553 & 14669 \\
Mean No. of matches played (n) & 26.8 & 27.8 & 28.8 & 32.3 & 28.8 \\
Mean No. of injuries/injured player (n) & 4.6 & 4.7 & 4.1 & $8.1^{* * *}$ & 4.8 \\
Injury risk, per played match (\%) & 13.0 & 11.8 & $9.8^{* *}$ & 11.7 & 11.2 \\
\hline
\end{tabular}

Legend: Players $\times$ matches - Total number of matches every subject played; Significantly different from all other categories of players: $* * \mathrm{p}<0.01 ; * * * \mathrm{p}<0.001$

Table 3. Percent distribution of injuries by body parts and player categories

\begin{tabular}{lrrrr}
\hline \multicolumn{1}{c}{ Category } & Keepers & Defence & Mid-field & Forward \\
Body part & $\mathrm{n}=48$ & $\mathrm{n}=194$ & $\mathrm{n}=189$ & $\mathrm{n}=79$ \\
\hline Head/neck & 4.8 & 5.2 & 9.0 & 11.0 \\
Upper extremity & 29.3 & 27.5 & 22.5 & 21.7 \\
Trunk & 4.8 & 7.5 & 8.1 & 5.4 \\
Lower extremity & 61.1 & 59.8 & 60.4 & 61.9 \\
\hline
\end{tabular}

The distribution of injuries by body parts was in all categories of players alike except the forwards, in whom the proportion of head/neck to trunk injuries was significantly $(\mathrm{p}<0.05)$ higher. On average, the frequencies of injuries of lower and upper extremities amounted to about 60 and 25\%, respectively (cf. Table 3).

A detailed analysis of the latter injuries (Table 4) revealed that, generally, hand and foot injuries dominated but interesting between-category differences were noted. Hand injuries were most pronounced in mid-field players and were exceeded about threefold injury frequencies of other segments of upper extremities. As to lower extremities, foot injuries dominated in all categories. Hip injuries were least frequent in mid-field players and most frequent in the forwards $(\mathrm{p}<0.001)$, and knee injuries were more frequent $(\mathrm{p}<0.05)$ in mid-field and forward players compared with other ones.

Table 4. Detailed percent distribution of injuries of upper and lower extremities

\begin{tabular}{|c|c|c|c|c|}
\hline $\begin{array}{l}\text { Category } \\
\text { Body part }\end{array}$ & $\begin{array}{c}\text { Keepers } \\
n=48\end{array}$ & $\begin{array}{c}\text { Defence } \\
n=194\end{array}$ & $\begin{array}{c}\text { Mid-field } \\
\mathrm{n}=189\end{array}$ & $\begin{array}{c}\text { Forward } \\
n=79\end{array}$ \\
\hline \multicolumn{5}{|c|}{ Upper extremity } \\
\hline Shoulder & $18.4^{\mathrm{b}}$ & 27.3 & $18.3^{\mathrm{b}}$ & 24.6 \\
\hline Arm & 24.5 & 21.6 & $13.3^{\mathrm{b}}$ & $16.9^{\mathrm{b}}$ \\
\hline Forearm & 20.4 & 22.7 & $18.3^{\mathrm{b}}$ & $18.5^{\mathrm{b}}$ \\
\hline Hand & 36.7 & 28.4 & 50.0 & 40.0 \\
\hline \multicolumn{5}{|c|}{ Lower extremity } \\
\hline Hip & 1.0 & 3.7 & 0.6 & 7.0 \\
\hline Thigh & $13.7^{\circ}$ & $16.8^{\circ}$ & $13.4^{\circ}$ & $14.1^{\circ}$ \\
\hline Knee & $19.6^{\circ}$ & $19.9^{\circ}$ & $26.7^{\circ} \wedge$ & $23.8^{\circ} \wedge$ \\
\hline Lower leg & $26.5^{\circ} \wedge$ & $25.9^{\circ} \wedge$ & $27.3^{\circ} \wedge$ & $22.7^{\circ} \wedge$ \\
\hline Foot & $39.2^{\circ} \wedge$ & $33.8^{\circ} \wedge$ & $32.0^{\circ} \wedge$ & $32.4^{\circ} \wedge$ \\
\hline
\end{tabular}

Significantly $(\mathrm{p}<0.05-0.001)$ different from: ${ }^{\mathrm{b}}$ Hand; ${ }^{\circ} \mathrm{Hip}$; $\wedge$ Knee 
Table 5. Percent distribution of injuries by body components and player categories

\begin{tabular}{lcccc}
\hline \multicolumn{1}{c}{ Category } & Keepers & Defence & Mid-field & Forward \\
Body part & $\mathrm{n}=48$ & $\mathrm{n}=194$ & $\mathrm{n}=189$ & $\mathrm{n}=79$ \\
\hline Bones & 1.2 & 0.8 & 1.5 & 2.0 \\
Joints & 9.0 & 12.7 & 11.1 & $17.4^{*}$ \\
Tendons & 15.0 & 15.6 & 16.1 & 13.7 \\
Muscles & 18.6 & 15.8 & 18.9 & 15.4 \\
Skin & 56.3 & 55.1 & 52.3 & 51.5 \\
\hline
\end{tabular}

* Significantly $(\mathrm{p}<0.05)$ higher than in other categories combined

Table 6. Detailed percent distribution of injuries of body components

\begin{tabular}{|c|c|c|c|c|}
\hline $\begin{array}{l}\text { Category } \\
\text { Body part }\end{array}$ & $\begin{array}{c}\text { Keepers } \\
\mathrm{n}=48\end{array}$ & $\begin{array}{l}\text { Defence } \\
\mathrm{n}=194\end{array}$ & $\begin{array}{c}\text { Mid-field } \\
n=189\end{array}$ & $\begin{array}{c}\text { Forward } \\
\mathrm{n}=79\end{array}$ \\
\hline \multicolumn{5}{|c|}{ Joints } \\
\hline Sprain & 73.3 & 80.2 & $62.7 * *$ & 75.0 \\
\hline Dislocation & 26.7 & 19.8 & $37.3^{* *}$ & 25.0 \\
\hline \multicolumn{5}{|c|}{ Tendons } \\
\hline Strain & 84.0 & 84.0 & 77.9 & 78.0 \\
\hline Tear & 16.0 & 16.0 & 22.1 & 22.0 \\
\hline \multicolumn{5}{|l|}{ Skin } \\
\hline Abrasion & 43.6 & 46.0 & 43.7 & 39.6 \\
\hline Laceration & 23.4 & 25.9 & 16.8 & 27.3 \\
\hline Haematoma & 19.1 & 16.5 & $23.7^{* * *}$ & 16.9 \\
\hline Ecchymosis & 13.8 & 11.6 & 15.8 & 16.2 \\
\hline
\end{tabular}

Significantly different from other categories combined: $* * \mathrm{p}<0.01$; $* * * \mathrm{p}<0.001$

When classifying injuries by body components, skin was the most frequently affected and accounted for over $50 \%$ of all injuries (Table 5), other components being rather evenly represented (13 - 17\%, on average) except bones (1.3\%). No significant between-category differences were noted except mid-field players, in whom the frequency of joint injuries was significantly $(\mathrm{p}<0.01)$ more frequent than in other players.

A detailed analysis of those injuries (Table 6) revealed rather uniform distribution of injuries among player categories, mid-field players being again an exception; the frequencies of joint dislocations and of haematomas were in them significantly higher than in other categories combined $(\mathrm{p}<0.01$ and $\mathrm{p}<0.001$, respectively).

\section{Discussion}

The presented results reflect the incidence and pattern of injuries sustained by professional Turkish football players over one game season. Cromwell et al. [3], in a study on 107 professional Welsh players, reported that $77 \%$ of injuries affected lower extremities, mainly soft tissues at the ankle being affected. Similar or higher frequencies were reported also by other authors $[1,5,14]$, thus, the $60.5 \%$ reported here was not an exceeding figure. Yoon et al. [13], in a study on 401 Asian players, reported $18.5 \%$ of knee injuries, $17.3 \%$ of lower leg and $14.2 \%$ of ankle injuries, with contusions dominating. Similar values were found in this study; knee injuries amounted to $19.8 \%$ in goal keepers and defence players but were significantly higher in mid-field and forward players (26\%). Moreover, the most frequent injuries found by us were skin abrasions and muscle strains. Our results differed from those of Yon which might have been due to differences in terminology used in the questionnaires.

Hawkins et al. [5] reported 6030 injuries in 91 professional football clubs throughout two seasons, $37 \%$ of those injuries being muscle strains, 19\% ligamentous sprains, $7 \%$ muscle sprains, $4 \%$ bone fractures and only 3 skin abrasions. In our study, among skin injuries which exceeded $50 \%$ of all injuries, abrasions ranged from 40 to $46 \%$, and the frequencies of muscle and tendon injuries were lower than in Hawkins' report.

In the study of Woods et al. [14], in which the preseason injuries $(n=6030)$ in the English professional football league were evaluated, $23 \%$ were related to thighs, $17 \%$ to knees, $17 \%$ to ankles, $12 \%$ to lower legs, $6 \%$ to feet and toes, $2 \%$ to hips and 3\% to upper extremities; in our study, the thigh injuries were markedly less frequent (about 15\%) and those of the knee, lower leg and foot were much higher with inverted trend along the lower extremity. Regarding the types of injuries, Wood reported muscle strains (37\%), muscle contusions (7\%), tendon injuries (5\%) and bone fractures (5\%). In our study, the percentage of tendon injuries was higher and those of bone fractures or muscle injuries markedly lower. The differences between the two studies might have, however, originated from different questionnaires and, perhaps, from different game styles.

Inklaar et al. [7] reported that thigh (23\%), knee (22\%) and ankle (23\%) were the most frequently injured, the distribution of injuries being not age-related; the most frequent injury types were sprains (31\%), contusions (28\%) and strains (19\%). In our study, the percentage of lower extremity injuries was similar (60.5\%) and that of strains and sprains (tendons and muscles combined) higher. Again, the differences could have been due to different conditions of playing fields. Moreover, Inklaar stated that sprain and strain injuries tended to afflict the same body parts resulting in continuous sufferings. 
The same observation was made by us and the likely reasons were most of the struggle taking place in the midfield, high fatigue and higher exposure to intervention.

Hoy et al. [6] studied 646 male and 69 female football players and reported that the most frequent were joint injuries (49\%) and skin lesions (30\%). Fractures were detected in $18 \%$ of the cohort, both upper and lower extremities being equally afflicted. In this study, joint injuries were decidedly lower and skin lesions were dominating in all player categories.

Schmidt-Olsen et al. [11] studied 496 male footballers aged 12 - 18 years; they found that most of the injuries affected lower extremities (70\%), especially knee (26\%) and ankle (23.1\%); head and neck injuries amounted to $1.2 \%$, upper extremity injuries $10.3 \%$ and back problems constituted $14 \%$ of all injuries. As much as $4 \%$ of injuries were bone fractures, mostly of upper extremities, the fractures being most likely due to the lack of experience of young players in falling down [11]. The incidence of fractures was significantly $(\mathrm{p}<0.001)$ higher than in our study while that of head/neck injuries significantly $(\mathrm{p}<0.001)$ lower.

Summing up, the study showed that injuries in football are a serious problem. As the coaches have a good practical knowledge of field incidents, a detailed overview of injuries may help them in taking appropriate preventive steps. It would appear that the approaches towards reducing the incidents, violence and repeated injuries ought to be supervised by physicians and physiotherapists, the coaches playing a key role.

\section{References}

1. Adamczyk G., L.Luboinski., (2002) Epidemiology of football - related injuries (Part I) A.Clin. 2:236-250.

2. Arnason A., S.B.Sigurdsson, A.Gudmundsson, I.Holme, L.Engebretsen, R.Bahr (2004) Physical fitness, injuries and team performance in football. Med.Sci.Sports Exerc. 36: 278-285.
3. Cromwell F., J.Walsh, J.Gormley (2000) A pilot study examining injuries in elite Gaelic footballers. Br.J.Sports Med. 34:104-108 DOI:10.1136/bjsm.34.2.104.

4. Drovak J., A.Junge (2000) Football injuries and physical symptoms, a review of the literature. Am.J.Sports Med. 2:3-9.

5. Hawkins R.D., M.A.Hulse, C.Wilkinson, A.Hodson, M.Gibson (2001) The association football medical research programme: an audit of injuries in professional football. Br.J. Sports Med. 35: 43-47 DOI:10.1136/bjsm.35.1.43.

6. Hoy K., B.E.Lindblad, C.J.Terkelsen, H.E.Helleland, C.J. Terkelsen (2003) European football injuries - a prospective epidemiologic and socioeconomic study. Am.J.Sports Med. 20: 318-322 DOI:10.1177/036354659202000314.

7. Inklaar H., E.Bol, S.L.Schmikli, W.L.Mosterd (1996) Injuries in male football players: team risk analysis. Int.J.Sports Med. 17: 229-234.

8. Junge A., J.Drovak (2004) Football injuries, a review on incidence and prevention. Sports Med. 34: 929-938.

9. Price R.J., R.D.Hawkins, M.A.Hulse, A.Hodson (2004) The football association medical research programme: an audit of injuries in academy youth football. Br.J.Sports Med. 38:466471 DOI:10.1136/bjsm.2003.005165.

10. Rahmana N., T.Reilly, A.Lees (2002) Injury risk associated with playing actions during competitive football. Br.J.Sports Med. 36: 354-359.

11. Schmidt-Olsen S., U.Jorgensen, S.Kaalund, J.Sorensen (1991) Injuries among young football players. Am.J.Sports Med. 19:273-275.

12. Tumulty D. (1993) Physiological characteristics of elite football players. Sports Med. 16:80-96.

13. Yoon Y.S., M.Chai, D.W.Shin (2004) Football injuries at Asian tournaments. Am.J.Sports Med. 32:36-42.

14. Woods C., R.Hawkins, M.Hulse, A.Hodson (2002) The football association medical research programme: an audit of injuries in professional football-analysis of preseason injuries. Br.J.Sports Med. 36:436-441.

\section{Received 26.09.2010 \\ Accepted 30.12.2010}

(c) University of Physical Education, Warsaw, Poland 